\title{
Chapter 12 \\ Regulating Services of Bivalve Molluscs in the Context of the Carbon Cycle and Implications for Ecosystem Valuation
}

\author{
R. Filgueira, T. Strohmeier, and Ø. Strand
}

\begin{abstract}
The role of marine bivalves in the $\mathrm{CO}_{2}$ cycle has been commonly evaluated as the balance between respiration, shell calcium carbonate sequestration, and $\mathrm{CO}_{2}$ release during biogenic calcification; however, this individual-based approach neglects important ecosystem interactions that occur at the population level, e.g. the interaction with phytoplankton populations and benthic-pelagic coupling, which in turn can significantly alter the $\mathrm{CO}_{2}$ cycle. Therefore, an ecosystem approach that accounts for the trophic interactions of bivalves, including the role of dissolved and particulate organic and inorganic carbon cycling, is needed to provide a rigorous assessment of the role of bivalves as a potential sink of $\mathrm{CO}_{2}$. Conversely, the discussion about this potential role needs to be framed in the context of non-harvested vs. harvested populations, given that harvesting represents a net extraction of matter from the ocean. Accordingly, this chapter describes the main processes that affect $\mathrm{CO}_{2}$ cycling and discuss the role of non-harvested and harvested bivalves in the context of sequestering carbon. A budget for deep-fjord waters is presented as a case study.
\end{abstract}

\begin{abstract}
Chinese 摘要:海水双壳贝类在二氧化碳循环中的作用通常根据 基于呼吸作用、钙化作用和钻化期间二氧化碳释放进行评价。然而,这种基 于个体的评估方法并没有考虑种群水平的贝类与生态系统的相互作用。例 如, 贝类与浮游植物种群和底栖生物的相互作用, 这种相互作用可以明显改变 $\mathrm{CO}_{2}$ 循环过程。因此, 需要建立一套综合考虑溶解有机碳、溶解无机碳、颗粒 有机碳、颗粒无机碳等碳存在形态的生态系统方法来评估双壳贝类潜在的碳 汇作用。然而, 关于这种潜在作用的讨论需要在区分自然种群和养殖种群的 情况下进行, 因为养殖种群的最终收获其实是从海水中进行相关营养成分的 净提取。因此, 本章介绍了影响 $\mathrm{CO}_{2}$ 循环的主要过程, 并讨论了自然和养殖的 双壳贝类在碳移除过程中的作用。在挪威峡湾内的一个双壳贝类养殖区的碳 收支会作为一个案例研究进行展示。
\end{abstract}

\author{
R. Filgueira $(\bowtie)$ \\ Marine Affairs Program, Dalhousie University, Halifax, NS, Canada \\ Institute of Marine Research, Bergen, Norway \\ T. Strohmeier $\cdot \varnothing$. Strand \\ Institute of Marine Research, Bergen, Norway \\ e-mail: tore.strohmeier@imr.no; oivind.strand@imr.no
}


Keywords Bivalve $\cdot \mathrm{CO}_{2} \cdot$ Carbon cycling $\cdot$ Carbon trading system

关键词 双壳贝类 ・ 二氧化碳 ・ 碳循环 ・ 碳交易系统

\subsection{Introduction}

Bivalves are soft-bodied organisms protected by an external shell consisting of two hinged valves. The ratio shell:tissue in terms of weight is different across species and is habitat dependent within species (e.g. Newell and Hidu 1982; Rodhouse et al. 1984; MacDonald and Thompson 1985; Penney et al. 2008). For example, mussels cultured in suspended structures tend to have lighter shells than those in natural populations, which could be related to the feeding conditions in aquaculture facilities promoting faster growth and thinner shells (Aldrich and Crowley 1986), but also to the reduced predation pressure (Lowen et al. 2013). The shells of cultured bivalves can generally be considered residues although they are sometimes used as by-products in construction and agriculture (e.g. Rodríguez Álvaro et al. 2014; Varhen et al. 2017). Taking into account the global annual production of cultured bivalves is $\sim 14 \times 10^{6}$ tons, including clams, cockles, oysters, mussels and scallops (www.fao.org reporting 2015 data) and assuming an average contribution of shell to total body weight of $50 \%$ (general ballpark figure given that this varies greatly between species), shell represents a residue (potential by-product) of $\sim 7 \times 10^{6}$ tons, of which $95 \%$ is calcium carbonate.

The shell is an exoskeleton that offers protection against predators and adverse environmental conditions. Adductor muscles are attached to the shell providing the animal with the capability to close their valves, isolating the internal tissues from the environment, although the effectiveness varies across species. In the case of scallops, the rapid contraction of the adductor muscle forces the valves to quickly squeeze the intervalvar fluid, which creates a water jet that propels the scallop, providing them with swimming capabilities (Guderley and Tremblay 2016). The different shell shapes across bivalve species allowed this class of molluscs to colonize a variety of habitats (Stanley 1970). Marine bivalves are widely distributed from tropical to boreal waters, and can be found inhabiting a variety of substrates, ranging from rocky to soft bottoms, infaunal and epifaunal. Most marine bivalves are suspension-feeders and can reach high densities in the wild, e.g. oyster reefs or mussel beds. At high density, they are ecosystem engineers (sensu Jones et al. 1994). Bivalves can modify the physical environment, for example by preventing erosion (Jones et al. 1994). They can also modify the available resources for other species, by controlling phytoplankton populations and/or altering nutrient cycling (Mann and Powell 2007; Filgueira et al. 2015). Consequently, the effects of bivalves on biogeochemical cycles goes beyond the individual scale. Accordingly, an ecosystem scale approach in which these feedbacks are included becomes imperative when studying the implications of marine bivalves in biogeochemical cycles. 
The role of bivalves as ecosystem engineers and the need for an ecosystem approach become even more relevant when bivalves are cultured at high densities. Although the same ecosystem process can be conceptually applied to wild and cultured populations, the higher densities in aquaculture sites can significantly alter the magnitude of biogeochemical fluxes. For example, although cultured bivalves can exert a bottom-up nutrient control in stimulating primary production (Cranford et al. 2007; Jansen 2012), this positive effect is density dependent, with a resulting high bivalve biomass causing a reduction in primary production (Burkholder and Shumway 2011; Smaal et al. 2013). Given their ideal growing conditions, growth rates of cultured populations are usually higher than for wild populations; however, the most critical aspect of cultured bivalves is that their biomass is extracted from the ocean, a relevant consideration when comparing the role of wild versus cultured populations in biogeochemical cycles. The shells of wild bivalves will eventually dissolve in seawater, but those of cultured bivalves may end up on land. Note that some wild populations may also end up on land when they are commercially exploited (e.g. mussel or scallop dredging). Therefore, in this chapter bivalves will be considered according to two main categories: non-harvested (wild populations that are not harvested) and harvested (cultured and wild populations that are harvested). Separation of non-harvested and harvested populations is critical when evaluating the role of bivalves from each group in the $\mathrm{CO}_{2}$ cycle and, in general, when valuing ecosystem services.

The goal of this chapter is to describe the role of bivalves in the $\mathrm{CO}_{2}$ cycle with special emphasis on the specific role of their shells and the implications for ecosystem services valuation. To achieve this, the chapter has been structured accordingly:

- The role of calcifying organisms in the $\mathrm{CO}_{2}$ budget.- which describes the chemistry of shell formation.

- The influence of organic carbon on $\mathrm{CO}_{2}$ fluxes.- which describes the main processes involving organic carbon that are relevant to the $\mathrm{CO}_{2}$ cycle.

- Ecosystem services of non-harvested and harvested populations.- which describes the implications of harvesting bivalves as a food source in the context of a holistic valuation of ecosystem services.

- Case study - Norwegian cultured mussels.- in which the rationale described in previous sections is applied to the case of Norwegian cultured mussels.

- Conclusions.- which summarizes the most relevant findings of the chapter.

\subsection{The Role of Calcifying Organisms in the $\mathrm{CO}_{2}$ Budget}

Calcifying organisms are directly involved in two processes that release $\mathrm{CO}_{2}$. First, $\mathrm{CO}_{2}$ is released via the catabolism of ingested organic matter:

$$
\mathrm{CH}_{2} \mathrm{O}+\mathrm{O}_{2} \rightarrow \mathrm{CO}_{2}+\mathrm{H}_{2} \mathrm{O}
$$


and, second, it is released via calcium carbonate $\left(\mathrm{CaCO}_{3}\right)$ formation by biogenic calcification:

$$
\mathrm{Ca}^{2+}+2 \mathrm{HCO}_{3}^{-} \leftrightarrow \mathrm{CaCO}_{3}+\mathrm{CO}_{2}+\mathrm{H}_{2} \mathrm{O}
$$

This release of $\mathrm{CO}_{2}$ also induces shifts in the carbonate system:

$$
\mathrm{CO}_{2}+\mathrm{H}_{2} \mathrm{O} \leftrightarrow \mathrm{H}_{2} \mathrm{CO}_{3} \leftrightarrow \mathrm{H}^{+}+\mathrm{HCO}_{3}^{-} \leftrightarrow 2 \mathrm{H}^{+}+\mathrm{CO}_{3}^{2-}
$$

These processes depend on environmental conditions such as $\mathrm{pH}$, alkalinity, salinity, and temperature (Millero 1995; Lerman and Mackenzie 2005; Dickson 2010; Mackenzie and Andersson 2013).

The balance between the $\mathrm{CO}_{2}$ released in respiration and biogenic calcification and the net $\mathrm{C}$ sequestered as calcium carbonate have been used to evaluate the role of bivalves in the $\mathrm{CO}_{2}$ cycle. The available studies in which these processes have been quantified for bivalves is reviewed in Table 12.1. The units from the different studies have been converted to $\mathrm{g} \mathrm{C} \mathrm{m}^{-2} \mathrm{y}^{-1}$ for comparative purposes (conversion factors: $12 \mathrm{~g} \mathrm{C}$ in $100 \mathrm{~g} \mathrm{CaCO}_{3} ; 12 \mathrm{~g} \mathrm{C}$ in $1 \mathrm{~mol} \mathrm{CO}_{2}$ ). With the exception of the estimations from Hily et al. (2013), all other studies suggest that sequestration minus biocalcification and respiration is negative (Table 12.1), which suggests that bivalves are net generators of $\mathrm{CO}_{2}$. Hily et al. (2013) suggested that under specific environmental conditions Crassostrea gigas and Mytilus edulis can sequester carbon effectively after accounting for biocalcification and respiration. The disagreement between Hily et al. (2013) and the other studies (Table 12.1) seems to be related to the respiration flux in Hily et al. (2013) which is especially obvious when comparing the ratio between sequestration and respiration. The respiration values in Hily et al. (2013) are extremely low compared to the other studies (Table 12.1) when considering the carbon that is sequestered in the shell. This is even more striking given the fact that most of these studies, including Hily et al. (2013), use the same empirical equation proposed by Schwinghamer et al. (1986) to estimate respiration. Nevertheless, aside from Hily et al. (2013), the level at which bivalves release $\mathrm{CO}_{2}$ is species dependent, with a net carbon release ranging from 0.35 to $2.45 \mathrm{gC}$ $\mathrm{m}^{-2}$ year $^{-1}$ per $1 \mathrm{gC} \mathrm{m}^{-2} \mathrm{year}^{-1}$ (Table 12.1). The results of several studies (see Table 12.1) demonstrate that bivalves are $\mathrm{CO}_{2}$ generators when the balance strictly focuses on this inorganic form of carbon at the individual level.

Solely from the individual perspective, it makes sense that a filter feeder is a net generator of $\mathrm{CO}_{2}$. The deposition of calcium carbonate generates a small net sequestration explicitly resulting from individual biocalcification given that the precipitation of $1 \mathrm{~mol}$ of $\mathrm{CaCO}_{3}$ releases approximately $0.6 \mathrm{~mol}$ of $\mathrm{CO}_{2}$ (Ware et al. 1992). But this net sequestration $\left(1.0-0.6=0.4 \mathrm{~mol}\right.$ of $\mathrm{CO}_{2}$ per mol of $\left.\mathrm{CaCO}_{3}\right)$ is not enough to compensate the $\mathrm{CO}_{2}$ that is released due to the catabolism of organic matter. Nevertheless, scaling these numbers up from the individual to the ecosystem level is not a trivial task. In a controversial paper, Tang et al. (2011) proposed that bivalve (and seaweed) aquaculture could increase atmospheric $\mathrm{CO}_{2}$ absorption within coastal ecosystems. These authors did not account for the release of $\mathrm{CO}_{2}$ via 


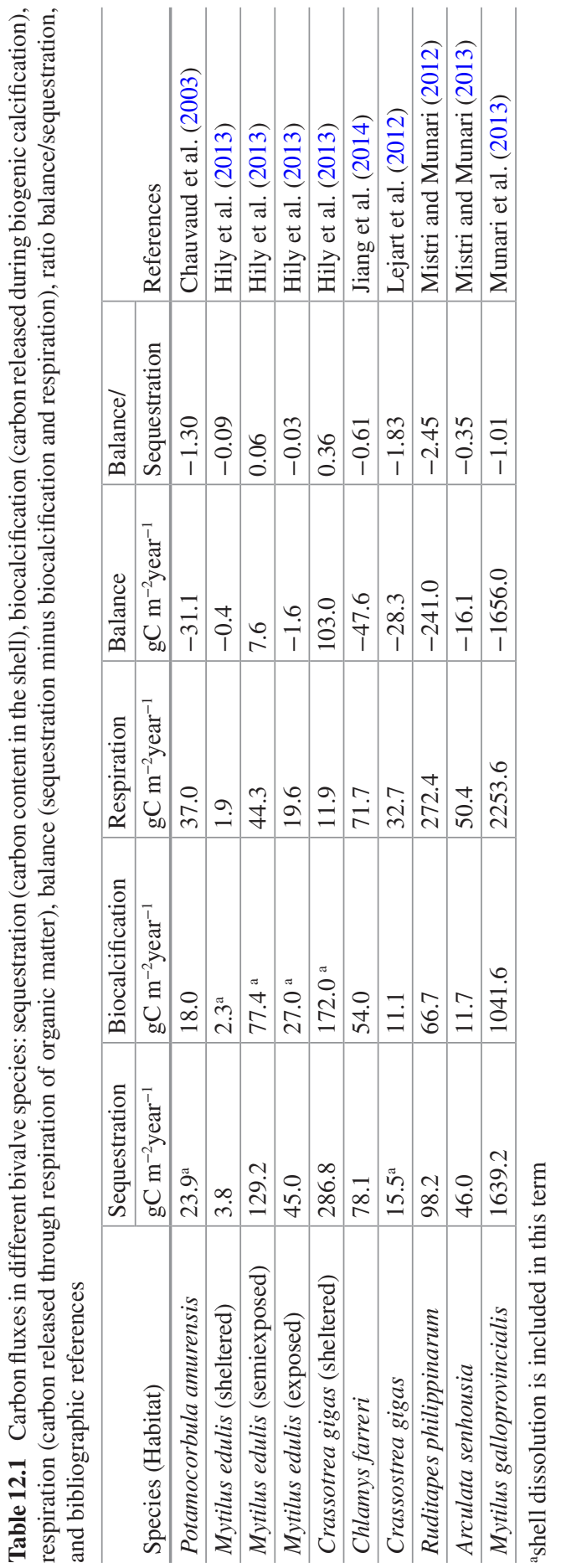


respiration in their budget (see Mistri and Munari 2013; Munari et al. 2013) but they argued for the inclusion of some relevant ecosystem effects when scaling up from the individual to the ecosystem level. For example, Tang et al. (2011) suggested that in a strongly autotrophic system, $\mathrm{CO}_{2}$ released by carbonate precipitation may be used by photosynthetic organisms, resulting in a lower transfer of $\mathrm{CO}_{2}$ from water to the atmosphere. They also suggested that removing shells from the oceans presents a long-term carbon sink. The slow dissolution of shells in the oceans, e.g. $\sim 29$ years for a 4-year old oyster excluding abrasion effects from waves and dissolution after burial (Suykens et al. 2011), provides a buffering capacity of respiratory acids to the environment (Waldbusser et al. 2013). Consequently, this removal can cause a loss of alkalinity regeneration and buffering of metabolic acids, which could affect ecosystem functioning (Waldbusser et al. 2013). These effects on water chemistry highlight that a simple multiplicative extrapolation from the individual to the ecosystem level oversimplifies the role of bivalves in the ecosystem. As stated by Lejart et al. (2012), the contribution of $C$. gigas to total carbon fluxes should be estimated for the entire community and not just for oysters. In addition, as stated by Waldbusser et al. (2013), the final destination of the shells can be relevant for ecosystem functioning and consequently has a feedback on the bivalves themselves. Clearly an integrated approach is required in which the ecosystem as well as anthropogenic aspects are simultaneously considered.

\subsection{The Influence of Organic Carbon on $\mathrm{CO}_{2}$ Fluxes}

The strong coupling between inorganic and organic carbon cycles is fundamental for scaling up from individual to population fluxes. This is even more critical in aquaculture sites, where bivalve populations are artificially maintained at generally high densities. The ecosystem role, and implications on the $\mathrm{CO}_{2}$ cycle, of dense bivalve populations can be very complex due to cascading effects, e.g. indirect effects on fish species via zooplankton consumption (Gibbs 2007; Kluger et al. 2017). Only the direct bivalve ecophysiological processes will be discussed in this chapter. The five main, direct ecophysiological processes of bivalves within the carbon cycle are: (1) respiration, which implies a net release of $\mathrm{CO}_{2}$ (discussed above); (2) biocalcification, which involves a net sequestration of carbon (discussed above); (3) food ingestion; (4) rejection of uningested food; and (5) egestion of unabsorbed food. In addition, an indirect link with the carbon cycle is carried out by excreted nutrients (Fig. 12.1). Although ingestion, rejection, egestion, and excretion are not directly involved in the inorganic carbon cycle, they are key processes for phytoplankton dynamics, which in turn play a key role in the $\mathrm{CO}_{2}$ cycle.

Bivalve ingestion may cause a direct top-down control on zooplankton (Maar et al. 2008) and phytoplankton populations (Dame 1996; Dame and Prins 1998; Newell 2004; Petersen et al. 2008; Huang et al. 2008). The net effects are strongly dependent on bivalve biomass and its relation to local environmental conditions, mainly water residence time and phytoplankton production rates (Dame and Prins 


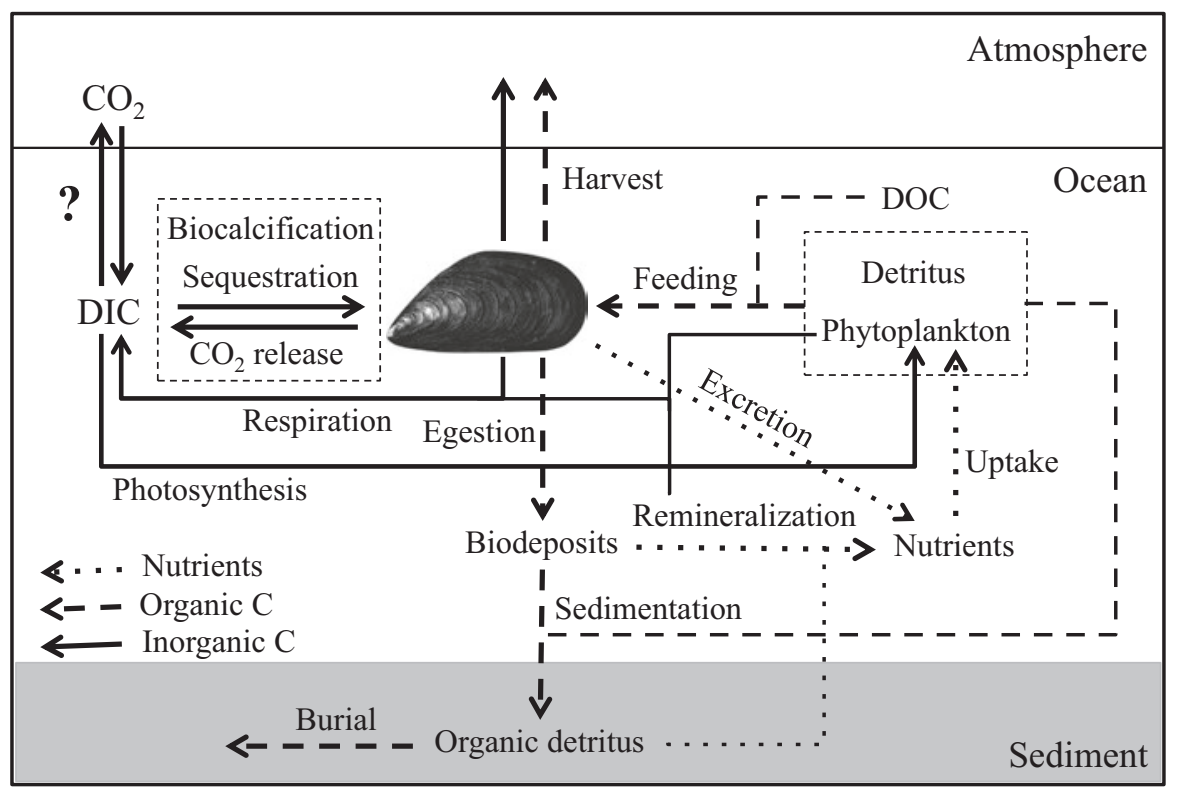

Fig. 12.1 Ecosystem approach to carbon cycling (continuous and dashed lines for organic and inorganic carbon, respectively) and feedbacks of mussel aquaculture on the pool of inorganic nutrients (dotted line). (Adapted for $\mathrm{C}$ from Cranford et al. 2012)

1998), which represent the renewal of planktonic resources driven by allochthones and autochthonous processes, respectively. If filtration capacity dominates over renewal, planktonic communities could be negatively affected (e.g. Heral 1993; Prins et al. 1998; Maar et al. 2007, 2010). This effect on planktonic biomass could have a direct effect on $\mathrm{CO}_{2}$ dynamics although secondary local drivers could also exert a significant influence on the net fluxes. For example, in nutrient-limited systems, the reduced phytoplankton population could accelerate its turnover rate by using the additional available nutrients, which in turn could result in the same levels of $\mathrm{CO}_{2}$ fixation as for a larger population (Newell 2004). Contrarily, in light-limited systems, the increase in filtration pressure usually causes a decrease in phytoplankton biomass and primary production (Cloern et al. 2007; Smayda 2008). This effect can be relaxed if filtration activity is sufficient to increase water clarity and light penetration (Cerco and Noel 2007; Schröder et al. 2014), which could stimulate phytoplankton growth and consequently $\mathrm{CO}_{2}$ fixation. In addition to the changes in biomass, the structure of phytoplankton communities could also be affected due to the increasing retention efficiency from small to large particles (Jacobs et al. 2015; Cranford et al. 2016). This differential retention efficiency may benefit the relative abundance of the smallest planktonic species (e.g. Vaquer et al. 1996; Smaal et al. 2013; Froján et al. 2014); however, this is a site-specific effect, as demonstrated by Sonier et al. (2016), who could not find any changes in the ratio picoplankton:nanoplankton in a densely cultured site in Atlantic Canada. In any case, the potential alteration of a phytoplankton community could have an effect on $\mathrm{CO}_{2}$ fluxes. 
During the feeding process, phytoplankton and particulate organic matter are consolidated into pseudofaeces (rejected uningested material) and faeces (egested unabsorbed material). These biodeposits sink to the seafloor and their fates are highly dependent upon local environmental conditions (Carlsson et al. 2009, 2010; Jansen 2012). The hydrodynamic regime is relevant not only for determining the horizontal advection of the biodeposits (Pearson and Black 2001; Grant et al. 2005), but also for their potential disaggregation (Driscoll 1970). The remineralization of the biodeposits begins in the water column and consequently the amount of organic matter that reaches the bottom is dependent on water depth. This vertical flux is critical for pelagic-benthic coupling and consequently for $\mathrm{CO}_{2}$ dynamics. For example, in shallow systems, biodeposits accumulated on the seafloor are exposed to very dynamic conditions in which resuspension and mixing can play important roles in determining remineralization rates or organic matter (Findlay and Watling 1997). In contrast, in deep fjord-type systems, sedimentation of biodeposits could transfer carbon to deep waters, potentially reaching the sediment (Sepúlveda et al. 2005), which can be considered as a carbon sequestering compartment. In addition to hydrodynamics and depth, other local conditions such as grain size, temperature, dissolved oxygen, presence/absence of seagrass, infauna, etc. determine the assimilative capacity of the benthos (Kusuki 1981; Souchu et al. 2001; Mitchell 2006). These local processes, in conjunction with bay-scale aspects such as terrestrial organic inputs and stoichiometry of nutrient inputs, define bay-scale dynamics and ultimately ocean-atmosphere $\mathrm{CO}_{2}$ fluxes (Laruelle et al. 2010; Bauer et al. 2013).

The remineralization of biodeposits on the seafloor enhances the fluxes of nutrients under highly dense bivalve populations (e.g. Carlsson et al. 2009; Alonso-Pérez et al. 2010). In addition, bivalve ammonia excretion constitutes another source of nitrogen that can be directly used by phytoplankton (e.g. Smaal and Prins 1993; Sara 2007). Nitrogen is probably the most limiting nutrient in coastal marine ecosystems in the temperate zone (Howarth and Marino 2006). Therefore, in nutrientlimited systems, bivalve ammonia excretion can enhance primary production (Smaal 1991; Prins et al. 1995, 1998; Pietros and Rice 2003). This bottom-up control on phytoplankton populations has been demonstrated for aquaculture sites emplaced in nutrient-limited systems such as in Grande-Entrée Lagoon (Canada, Trottet et al. 2008) or Narragansett Bay (USA, Oviatt et al. 2002). Bottom-up control effectively accelerates phytoplankton turnover and primary production rates, which directly increase the net $\mathrm{CO}_{2}$ fixation via photosynthesis, thereby accelerating carbon assimilation into the biosphere.

\subsection{Ecosystem Services of Non-Harvested and Harvested Populations}

The chemical and ecological aspects discussed above can be directly applied to both non-harvested and harvested populations; however, the final destination of the bivalve is a critical aspect that needs to be considered when valuing ecosystem 
services. For example, as stated above, the final destination of the shells can be relevant for water chemistry and consequently for ecosystem functioning (Waldbusser et al. 2013). In the case of non-harvested populations, the shells remain in the ocean but the final destinations of harvested bivalves are diverse, from waste to building materials (e.g. Rodríguez Álvaro et al. 2014; Varhen et al. 2017), agricultural usage or the production of lime (calcium oxide $\mathrm{CaO}$ ), which could be used to remove phosphates from rural watersheds (Abeynaike et al. 2011). This difference is fundamental for the shell, but it is even more critical when the meat of the bivalve is part of the equation. In the case of non-harvested bivalves, the tissue will become part of the food web via predation and decomposition after death. Food provision via the meat of harvested bivalves is the primary goal of culturing bivalves. Although these differences are meaningless when discussing the role of bivalves as a whole in the $\mathrm{CO}_{2}$ cycle, they become very important when valuing ecosystem services. Therefore, in the case of non-harvested bivalves that are not harvested to provide food, the analysis of their role on the $\mathrm{CO}_{2}$ cycle should only include the chemical and ecological aspects discussed above. In the case of harvested bivalves, however, a clear distinction between the tissue, which is the main product of this economic activity, and the shell, which usually is considered waste, can be made when valuing their ecosystem services.

In the most extreme scenario, it can be argued that the shell has no marketable value and should be considered waste. In that situation, the carbon sequestered in the shell could be used to valorize the waste and create a by-product for carbon sequestration. Consequently, in that scenario all the $\mathrm{CO}_{2}$ released from biocalcification and respiration should be accounted towards the $\mathrm{CO}_{2}$ budget of the product, the meat. This would result in valuing the waste (shell) as a by-product that constitutes a net sink of carbon independent of the $\mathrm{CO}_{2}$ released during the biocalcification and respiration. An alternative, and probably more logical, accountability would be to split the $\mathrm{CO}_{2}$ fluxes towards shell and meat as a function of the biological processes involved in their formation. This implies splitting all the ecosystem fluxes and respiration among shell and meat as a function of their energetic demand. Splitting the energetic demand of a bivalve between shell and meat is not straightforward. It is commonly accepted that most of the energy is allocated towards maintenance, tissue growth and reproduction rather than shell growth. Nevertheless, the exact fraction of total energy that is invested in shell growth is unknown in part because any estimation is highly dependent on local environmental conditions. For example, habitat (Fig. 12.2, Rodhouse et al. 1984), feeding conditions (Aldrich and Crowley 1986), hydrodynamics (Steffani and Branch 2003) and predation pressure (Lowen et al. 2013) can all affect the energy allocation towards shell.

The lack of specific studies on energy allocation and the effects of local conditions on growth investment becomes a serious limitation when trying to split carbon fluxes between shell and tissue. The available data are limited to the estimations by Hawkins and Bayne (1992) who suggested that Mytilus edulis could spend more than $20 \%$ of the energy that is available for growth on shell formation. This matches with the calculations of Duarte et al. (2010), who indirectly estimated that Mytilus galloprovincialis could invest $20-28 \%$ of the energy that is available for growth in 


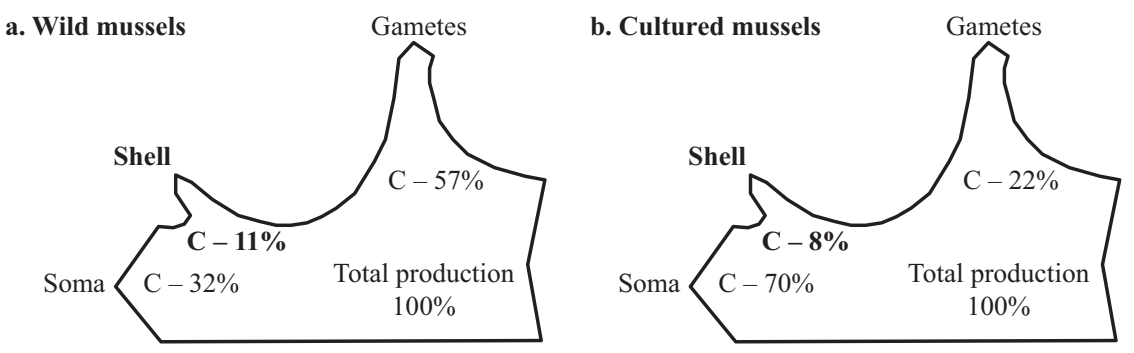

Fig. 12.2 Allocation of carbon in wild and cultured Mytilus edulis. (From Rodhouse et al. 1984)

shell formation. It is important to highlight that these estimations establish the energy that is available for growth as a bottom line for the calculations, in other words, the available energy after paying maintenance, digestion/absorption and growth costs (Scope For Growth, Winberg 1960). The shell does not require any maintenance costs, with the exception of repairing mechanical damage, and consequently allocating 20-28\% (based on Duarte et al. 2010) of the total $\mathrm{CO}_{2}$ fluxes towards shell would overestimate the energetic requirements of shell growth. Accordingly, for the following estimated calculations, $10 \%$ has been assumed as the percentage of the total energetic demands that is allocated towards shell (with the remaining $90 \%$ allocated towards maintenance and tissue growth).

As explained above, all the processes in the full ecosystem approach towards the quantification of $\mathrm{CO}_{2}$ fluxes should be split between tissue and shell according to this 10/90\% estimation. For these preliminary calculations and for simplicity, the following calculations have included only biocalcification and respiration in the $\mathrm{CO}_{2}$ budget, following the approach presented in Table 12.1. Accordingly, the respiration values provided in Table 12.1 have been re-calculated in Table 12.2 by considering only $10 \%$ of the total respiration, which would represent the $\mathrm{CO}_{2}$ flux that corresponds to the shell energetic requirements. The datasets from Hily et al. (2013) have been removed from this table due to the uncertainties highlighted above. Splitting respiration provides a general budget for shell $\mathrm{CO}_{2}$ fluxes (Table 12.2) rather than for the whole individual (Table 12.1). According to the Table 12.2 calculations and in the context of harvested bivalves, the shells, which are waste of an industrial process, could be considered net sinks of $\mathrm{CO}_{2}$ and consequently valorized as by-products. It should be re-emphasized that this reasoning is based on the assumption that humans culture bivalves with the aim of producing food and not sequestering $\mathrm{CO}_{2}$ and consequently, from the perspective of ecosystem services the $\mathrm{CO}_{2}$ generated through respiration should be split between meat and shell.

The next logical question is: is this sequestered carbon relevant from a global perspective? As stated above, cultured bivalves produce $\sim 7 \times 10^{6}$ tons of shell per year. Taking into account that $95 \%$ is calcium carbonate, and $12 \%$ of that is carbon, shells contain $8 \times 10^{5}$ tons of carbon per year. Assuming that shell growth demands $10 \%$ of total energy and the net sequestration of carbon in the shell is $\sim 21 \%$ (aver- 


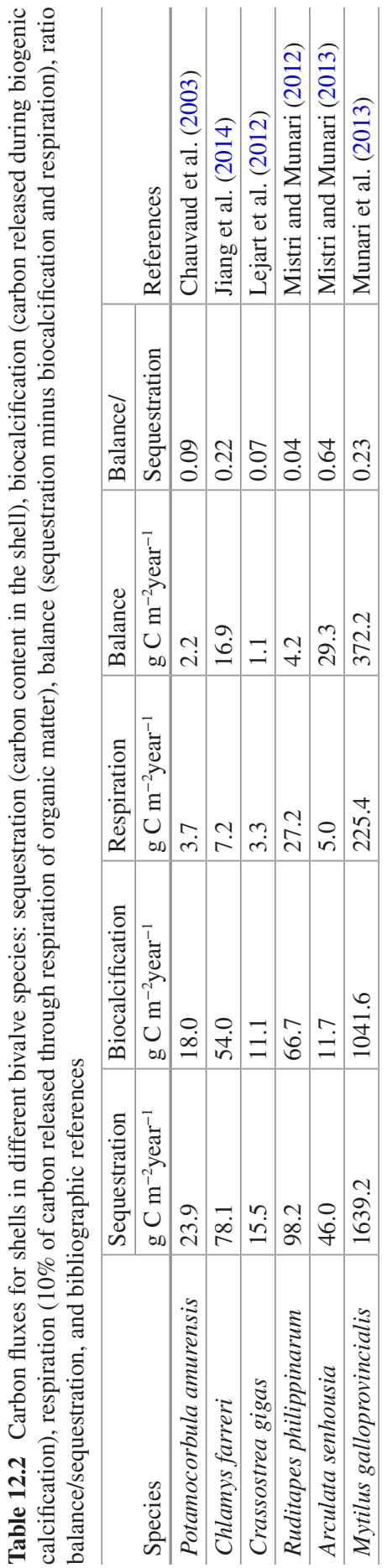


age value of Balance/Sequestration column in Table 12.2), $1.71 \times 10^{5}$ tons of carbon, or $6.3 \times 10^{5}$ tons of $\mathrm{CO}_{2}$ equivalent, per year are effectively sequestered in shells of cultured bivalves. In economic terms, the impact highly depends upon the carbon initiative that values a ton of $\mathrm{CO}_{2}$, which can range from US\$131 in the Swedish carbon tax, to US\$1 in Mexico (World Bank et al. 2016). Assuming an average value of US\$24 per ton of $\mathrm{CO}_{2}$ (average for Denmark, France, United Kingdom, British Columbia and Ireland; World Bank et al. 2016) the global value of the carbon effectively sequestered in shells of cultured bivalves is $\sim 15.7$ million US\$ per year. This amount represents less than $0.01 \%$ of the total bivalve aquaculture value.

\subsection{Case-Study: Norwegian Cultured Mussels}

Marine carbon burial is the main natural mechanism of long-term organic carbon sequestration (Berner 1982; Hedges et al. 1997). Fjords are deep, glacially carved estuaries situated at high latitudes. Smith et al. (2015) estimated that $18 \times 10^{6}$ tons carbon is buried in fjord sediment each year. This is equivalent to $11 \%$ of the annual marine carbon burial globally, and makes the fjord organic carbon burial rate 100 times more efficient than the global ocean average, per unit area. As stated above, local conditions are critical for the implications of cultured bivalves on the $\mathrm{CO}_{2}$ cycle. The estimation of the $\mathrm{CO}_{2}$ budget of mussel (Mytilus edulis) farming in a Norwegian fjord has been selected as a case-study to guide the application of the rationale described in this study to a cultured system. It is important to emphasize that due to the effects of the cultured species and local conditions, the following calculations cannot be extrapolated to other bivalves or locations.

The $\mathrm{CO}_{2}$ budget is based on the life history of a 2-year old mussel, the typical lifespan of mussels in suspended culture in Norway. The mussel is harvested before reproduction, and obtains a dry shell weight (DSW) of $4.8 \mathrm{~g}$ and a dry tissue weight of $1.0 \mathrm{~g}$. It is assumed that $85 \%$ of farmed mussels will be harvested and $15 \%$ will fall off their ropes during strong winds and wave action, farm operation, density control/thinning, harvest and predation (Strohmeier et al. 2008). As a consequence of low food quantity and high food quality, mussels have not been reported to reject uningested food in Norwegian fjords (Strohmeier et al. 2015). Following the rationale described above, the $\mathrm{CO}_{2}$ fluxes were split between the shell and the tissue according to their presumed energetic demand.

\subsubsection{Respiration}

Throughout their life history, mussels consume oxygen and release $\mathrm{CO}_{2}$ as a result of the catabolism of organic matter. The oxygen required for the mussel growth has been estimated by allometric scaling (Bayne and Widdows 1978; Thompson 1984; 
Fig. 12.3 $\mathrm{CO}_{2}$ fluxes (total $\mathrm{g} \mathrm{CO}_{2}$ per mussel) in cultured Norwegian mussel

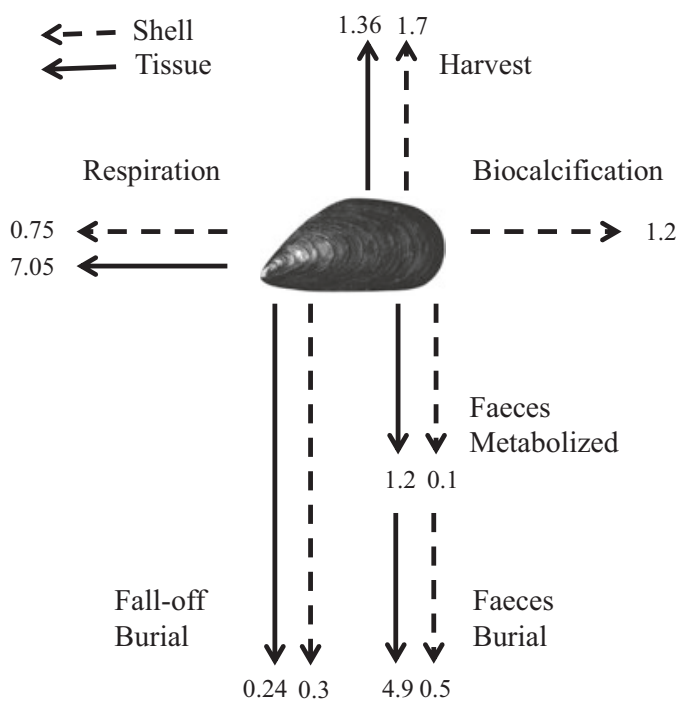

Smaal et al. 1997) and a Dynamic Energy Budget (DEB) model parameterized for Norwegian mussels (Rosland et al. 2009), using a seasonal time series of mussel growth and ecophysiology that included respiration data (Strohmeier 2009; Strohmeier et al. 2015). The results indicated a cumulative oxygen consumption of 4.5 to $8.8 \mathrm{~g}$. Assuming a respiratory quotient towards herbivory (0.85, Galtsoff 1964), this results in a cumulative release of 0.12 to $0.23 \mathrm{~mol}$ or 5.3 to $10.3 \mathrm{~g} \mathrm{CO}_{2}$. Splitting the $\mathrm{CO}_{2}$ fluxes between shell and tissue according to the $10 / 90 \%$ outlined above, the allocated catabolism of the shell represents 0.5 to $1 \mathrm{~g} \mathrm{CO}_{2}$ (mean 0.75 , Fig. 12.3) and the catabolism of the tissue from 4.8 to $9.3 \mathrm{~g} \mathrm{CO}_{2}$ (mean 7.05, Fig. 12.3).

\subsubsection{The Shell}

The deposit of $\mathrm{CaCO}_{3}$ in a $4.8 \mathrm{~g}$ mussel shell sequesters $0.55 \mathrm{~g}$ carbon or $2.0 \mathrm{~g} \mathrm{CO}_{2}$. The flux of $\mathrm{CO}_{2}$ due to shell formation to land (harvest) and seabed (fall off) is 1.7 and $0.3 \mathrm{~g} \mathrm{CO}_{2}$, respectively (Fig. 12.3). The amount of $\mathrm{CO}_{2}$ released during biocalcification for the same individual is $1.2 \mathrm{~g}$. Therefore, the net sequestration in the shell is $0.8 \mathrm{~g} \mathrm{CO}_{2}$. Including the associated cost of respiration (10\%) to the net sequestration of $\mathrm{CO}_{2}$ in the shell results in a balance (sequestration minus biocalcification and respiration) in the range -0.2 to $0.3 \mathrm{~g} \mathrm{CO}_{2}$, which accounts for all the relevant fluxes at the individual level needed to define the $\mathrm{CO}_{2}$ budget (e.g. Table 12.1). Under the assumption that $85 \%$ of the mussels are harvested and $15 \%$ fall off, the mean balance indicates a net flux of $0.04 \mathrm{~g} \mathrm{CO}_{2}$ to land (harvest) and $0.01 \mathrm{~g} \mathrm{CO}_{2}$ to the seabed (fall off). 


\subsubsection{The Tissue}

The carbon content of the tissue shows seasonal variation, with a mean value of $0.44 \mathrm{~g} \mathrm{C}$ per gram of dry weight (range 0.40-0.47, Jansen 2012). The mean carbon content of a $1 \mathrm{~g}$ of mussel's tissue in terms of dry weight is thereby $0.44 \mathrm{~g}$, corresponding to $1.61 \mathrm{~g} \mathrm{CO}_{2}$. The flux of $\mathrm{CO}_{2}$ to land (harvest) and seabed (fall off) is thus 1.36 and $0.24 \mathrm{~g} \mathrm{CO}_{2}$, respectively (Fig. 12.3). Inclusion of the associated cost of catabolism ( $90 \%$ ) results in a net balance (sequestration minus catabolism) in the range from -7.7 to $-3.2 \mathrm{~g} \mathrm{CO}_{2}$. The mean balance indicates a net flux of $-4.9 \mathrm{~g} \mathrm{CO}_{2}$ to land (harvest) and $-0.5 \mathrm{~g} \mathrm{CO}_{2}$ to seabed (fall off).

\subsubsection{Egestion of Unabsorbed Food}

The cumulative mass and carbon content of fecal pellets has been estimated based on Jansen et al. (2012) and the DEB model (Rosland et al. 2009). The results indicate that a mussel egests $12.9-13.7 \mathrm{~g}$ faeces over the 2 year period in terms of dry weight. The fecal pellets comprise a $\mathrm{C}$ fraction of $13.5 \%$ (Jansen 2012). The cumulative egestion is thereby 1.7-1.9 $\mathrm{g} \mathrm{C}$ or 6.4-7.0 $\mathrm{g} \mathrm{CO}_{2}$. Faeces contain fresh biological material, and may be used as a food source by other organisms until they are buried in the sediment. Faeces were assumed to enter the pelagic environment after being "trapped" on the mussel collectors for a brief period of time, then they sink towards the seabed (Jansen et al. 2012). The sinking velocity of fecal pellets, obtained for mussels grazing on natural seston, has been reported at $3.9 \mathrm{~mm} \mathrm{~s}^{-1}$ or $337 \mathrm{~m} \mathrm{~d}^{-1}$ (Carlsson et al. 2010). Overall, the residence time for faeces in the pelagic environment was set to two days, representing the average depth of a Norwegian fjord of about $300 \mathrm{~m}$.

Faeces contain a labile faction that can be fully catabolized in oxygenated water on a timescale ranging from 5 to 15 days, depending on the season (Jansen 2012). Here a constant decay and 10 days to fully catabolize the fecal matter is assumed. Taking into account the average sinking time of 2 days, $80 \%$ of the faeces will reach the seabed (mean $1.4 \mathrm{~g} \mathrm{C}$ or $5.4 \mathrm{~g} \mathrm{CO}_{2}$ ), while $20 \%$ will be metabolized in the pelagic environment $\left(0.4 \mathrm{~g} \mathrm{C}\right.$ or $\left.1.3 \mathrm{~g} \mathrm{CO}_{2}\right)$. Splitting these fluxes according to the associated energy demand of shell (10\%) and tissue (90\%), 0.1 and $1.2 \mathrm{~g} \mathrm{CO}_{2}$ of the fecal matter will be respired in the pelagic environment, and 0.5 and $4.9 \mathrm{~g} \mathrm{CO}_{2}$ will reach the sediment for shell and tissue, respectively (Fig. 12.3). In deep anoxic fjords a high carbon burial rate can be expected, and in this budget it is assumed that the carbon that reaches the seabed is not metabolized further. 


\subsubsection{General Budget in the Context of Ecosystem Services}

The balance for the shell and tissue was estimated separately as: +burial of fall off mussel +burial of faeces +harvest of mussel -biocalcification -respiration -faeces respired in the water column. The balance for shell is $+0.45 \mathrm{~g} \mathrm{CO}_{2}(+0.3+0.5+1.7-$ $1.2-0.75-0.1$ ) suggesting that mussel shell of cultured mussels in a 2 year cycle in a Norwegian fjord can be considered a net sink of $\mathrm{CO}_{2}$, assuming that the harvested shells are disposed of in a way that can be considered sequestered material, e.g. concrete. The balance for tissue is $-3.11 \mathrm{~g} \mathrm{CO}_{2}(+0.24+4.9+0-0-7.05-1.2)$. Note that for tissue, $\mathrm{CO}_{2}$ towards the term 'harvest of mussel' has not been included in the budget. This flow of $\mathrm{CO}_{2}$ is assumed to be consumed and respired in the short term and consequently not sequestered in the long term. Accounting shell and tissue together, this budget confirms that mussels are, as expected, net sources of $\mathrm{CO}_{2}$.

This budget includes the traditional fluxes of respiration and biocalcification (e.g. Table 12.1), but also an additional direct ecosystem flux, the egestion of unabsorbed food. Given that in Norwegian waters the rejection of uningested food is negligible, the impact of bivalve ingestion and ammonia excretion would be the only two additional processes to assess for a holistic ecosystem approach to the $\mathrm{CO}_{2}$ budget. The $\mathrm{CO}_{2}$ fluxes have been split according to the biological process involved in the formation of the shell and tissue, based on their anticipated energetic demands (see text above). In valuing the ecosystem service of mussel farming in the carbon cycle a distinction has been made between the shell (waste) and the tissue (food). Following this rationale, the goods and services of mussel farming in deep fjords includes the valorization of the shells as a net sink of $\mathrm{CO}_{2}$.

The more holistic ecological approach reveals a previously unaccounted for, yet significant indirect carbon sequestration by deposition of mussel faeces in sediment. Given the assumption that all mussel faeces are buried in deep fjords, the sediment may sequester more than $60 \%$ of the total $\mathrm{CO}_{2}$ respired. In environments comprising high food quantities, mussels can produce a significant amount of pseudofaeces (rejected uningested material) in addition to fecal matter and thereby increase the organic flux to the seabed (Galimany et al. 2013). If this particulate matter, faeces and pseudofaeces, sinks into an environment where it is not further catabolized, then a net $\mathrm{CO}_{2}$ sequestering from mussel farming is plausible. This may serve as an example to encourage an ecosystem approach towards the quantification of bivalve $\mathrm{CO}_{2}$ fluxes.

A typical Norwegian mussel farm produces a volume from 50 to 150 tons each year equating to a mean farm production of about $6.25 \times 10^{6}$ mussels. Valuing the ecosystem service of mussel farming in the carbon cycle, the shells sequester 2.8 tons of $\mathrm{CO}_{2}$, or $146 \mathrm{US} \$$ per year (assuming US\$53 per ton of $\mathrm{CO}_{2}$ in Norway according to World Bank et al. (2016)). 


\subsection{Conclusions}

As expected and as proved in the literature (Table 12.1), given their nature as primary consumers, bivalves release $\mathrm{CO}_{2}$. The sequestration of $\mathrm{CO}_{2}$ in the shell is not enough to compensate the release generated during the respiration of organic matter. Note that the use of the term "production" was avoided within the manuscript in the context of bivalves "producing" $\mathrm{CO}_{2}$. This has been done intentionally to avoid negative connotations associated with being a $\mathrm{CO}_{2}$ generator. As discussed, all primary consumers release $\mathrm{CO}_{2}$ that was captured by primary producers. Accordingly, a better term could be "recycling" $\mathrm{CO}_{2}$ rather than a term that suggests the production of new $\mathrm{CO}_{2}$. In any case, in the context of ecosystem services, there are two fundamental aspects that should be also taken into account when estimating a $\mathrm{CO}_{2}$ budget: the consideration of ecosystem processes when scaling individual fluxes to the population level (e.g. Lejart et al. 2012), and the final destination of the bivalves (e.g. Waldbusser et al. 2013), that is, bivalves harvested for food production or nonharvested bivalves. Ecosystem processes involving bivalves are relevant and alter the $\mathrm{CO}_{2}$ cycle via filtration and/or nutrient cycling (Lejart et al. 2012). Consequently, they should be considered when the $\mathrm{CO}_{2}$ budget is calculated for bivalve populations. When valuing ecosystem services, it has been recognized that humans harvest bivalves to provide food and consequently shells should be considered waste. Accordingly, a different $\mathrm{CO}_{2}$ budget should be calculated for product (tissue) and waste (shell).

Under these considerations, bivalve shells can be considered net sinks of $\mathrm{CO}_{2}$ and consequently provide additional ecosystem services besides the food provided by the tissue. A full life cycle analysis should be performed to account for the emissions required to properly dispose of the shells. The $0.45 \mathrm{~g} \mathrm{CO}_{2}$ sequestered by the shell of each cultured mussel in Norway is hardly significant taking into account that a regular car produces more than $100 \mathrm{~g} \mathrm{CO}_{2}$ per $\mathrm{km}$. For example, since 2015 European Union law requires that new cars do not emit more than an average of $130 \mathrm{~g} \mathrm{CO}_{2}$ per km, with a target of $95 \mathrm{~g} \mathrm{CO}_{2}$ per km by 2021 (European Commission, Climate Action). Even when these numbers are extrapolated to the global scale, a conservative extrapolation of the individual bivalve budget to the global production would result in a sequestration of $6.3 \times 10^{5}$ tons of $\mathrm{CO}_{2}$ per year, $\sim 15.7 \times 10^{6} \mathrm{US} \$$ / year. In different units, this is equivalent to the annual emissions of 242,307 cars driving an average of $20,000 \mathrm{~km}$ each. Although this is far from solving a global problem, everything counts. In addition, it is important to re-emphasize that this comes at no cost or effort given that bivalves are cultured to produce food.

Acknowledgments We would like to thank Sandra Shumway and Gary Wikfors for their constructive and valuable reviews of the chapter. The work was partly based on results from two projects funded by the Research Council of Norway: Carrying Capacity in Norwegian Aquaculture (CANO) (project no. 173537) and Growth performance and detoxification of mussels cultured in a fjord enhanced by forced upwelling of nutrient rich deeper water (GATE) (project No. 196560). Further support was provided by the Natural Sciences and Engineering Research Council of Canada (NSERC Discovery Grant to RF). 


\section{References}

Abeynaike A, Wang L, Jones MI, Patterson DA (2011) Pyrolysed powdered mussel shells for eutrophication control: effect of particle size and powder concentration on the mechanism and extent of phosphate removal. Asia Pac J Chem Eng 6:231-286

Aldrich JC, Crowley M (1986) Condition and variability in Mytilus edulis (L.) from different habitats in Ireland. Aquaculture 52:273-286

Alonso-Pérez F, Ysebaert T, Castro CG (2010) Effects of suspended mussel culture on benthicpelagic coupling in a coastal upwelling system (Rı'a de Vigo, NW Iberian Peninsula). J Exp Mar Biol Ecol 382:96-107

Bauer JE, Cai WJ, Raymon PA, Bianchi TS, Hopkinson CS, Regnier PAG (2013) The changing carbon cycle of the coastal ocean. Nature 504:61-70

Bayne BL, Widdows J (1978) Physiological ecology of two populations of Mytilus edulis L. Oecologia 37(2):137-162

Berner RA (1982) Burial of organic carbon and pyrite sulfur in the modern ocean: its geochemical and environmental significance. Am J Sci 282:451-473

Burkholder JM, Shumway SE (2011) Bivalve shellfish aquaculture and eutrophication. In: Shumway SE (ed) Shellfish aquaculture and the environment. Wiley, New York, pp 155-215

Carlsson MS, Holmer M, Petersen JK (2009) Seasonal and spatial variations of benthic impacts of mussel longline farming in a eutrophic Danish fjord, Limfjorden. J Shellfish Res 28:791-801

Carlsson MS, Glud RN, Petersen JK (2010) Degradation of mussel (Mytilus edulis) fecal pellets released from hanging long-lines upon sinking and after settling at the sediment. Can J Fish Aquat Sci 67(9):1376-1387

Cerco CF, Noel MR (2007) Can oyster restoration reverse cultural eutrophication in Chesapeake Bay? Estuar Coasts 30:331-343

Chauvaud L, Thompson JK, Cloern JE, Thouzeau G (2003) Clams as $\mathrm{CO}_{2}$ generators: the Potamocorbula amurensis example in San Francisco Bay. Limnol Oceanogr 48:2086-2092

Cloern JE, Jassby AD, Thompson JK, Hieb KA (2007) A cold phase of the East Pacific triggers new phytoplankton blooms in San Francisco Bay. P Natl Acad Sci USA 104:18561-18565

Cranford PJ, Strain PM, Dowd M, Hargrave BT, Grant J, Archambault MC (2007) Influence of mussel aquaculture on nitrogen dynamics in a nutrient enriched coastal embayment. Mar Ecol Prog Ser 347:61-78

Cranford PJ, Kamermans P, Krause G, Mazurié J, Buck BH, Dolmer P, Fraser D, Nieuwenhove KV, O'Beirn FX, Sanchez-Mata A, Thorarisdóttir GG, Strand Ø (2012) An ecosystem-based approach and management framework for the integrated evaluation of bivalve aquaculture impacts. Aquac Environ Interact 2:193-213

Cranford PJ, Strohmeier T, Filgueira R, Strand Ø (2016) Potential methodological influences on the determination of particle retention efficiency by suspension feeders: Mytilus edulis and Ciona intestinalis. Aquat Biol 25:61-73

Dame RF (1996) Ecology of marine bivalves: an ecosystem approach. CRC Press, Boca Raton

Dame RF, Prins TC (1998) Bivalve carrying capacity in coastal ecosystems. Aquat Ecol 31:409-421

Dickson AG (2010) The carbon dioxide system in seawater: equilibrium chemistry and measurements. In: Riebesell U, Fabry VJ, Hansson L, Gattuso JP (eds) Guide to best practices for ocean acidification research and data reporting. Publications Office of the European Union, Luxembourg, pp 17-52

Driscoll EG (1970) Selective bivalve shell destruction in marine environments, a field study. J Sediment Petrol 40(3):898-905

Duarte P, Fernández-Reiriz MJ, Filgueira R, Labarta U (2010) Modelling mussel growth in ecosystems with low suspended matter loads. J Sea Res 64:273-286

Filgueira R, Comeau LA, Guyondet T, Mckindsey CW, Byron CJ (2015) Modelling carrying capacity of bivalve aquaculture: a review of definitions and methods. In: Meyers R (ed) Encyclopedia of sustainability science and technology. Springer, New York 
Findlay RH, Watling L (1997) Prediction of benthic impact for salmon net-pens based on the balance of benthic oxygen supply and demand. Mar Ecol Prog Ser 155:147-157

Froján M, Arbones B, Zúñiga D, Castro CG, Figueiras FG (2014) Microbial plankton community in the Ría de Vigo (NW Iberian upwelling system): impact of the culture of Mytilus galloprovincialis. Mar Ecol Prog Ser 498:43-54

Galimany E, Rose JM, Dixon MS, Wikfors GH (2013) Quantifying feeding behaviour of ribbed mussels (Geukensia demissa) in two urban sites (Long Island Sound, USA) with different seston characteristics. Estuar Coasts 36:1265-1273

Galtsoff PS (1964) Transport of water by the gills and respiration. In: Galtsoff PS (ed) The American oyster, Crassostrea virginica Gmelin, Fishery bulletin 64. U.S. G.P.O, Washington, DC

Gibbs MT (2007) Sustainability performance indicators for suspended bivalve aquaculture activities. Ecol Indic 7:94-107

Grant J, Cranford PJ, Hargrave B, Carreau M, Schofield B, Armsworthy S, Burdett-Coutts V, Ibarra D (2005) A model of aquaculture biodeposition for multiple estuaries and field validation at blue mussel (Mytilus edulis) culture sites in eastern Canada. Can J Fish Aquat Sci 62:1271-1285

Guderley HE, Tremblay I (2016) Swimming in scallops. In: Shumway SE, Parsons GJ (eds) Scallops: biology, ecology, aquaculture, and fisheries. Elsevier, San Diego, pp 535-566

Hedges JI, Keil RG, Benner R (1997) What happens to terrestrial organic matter in the ocean? Org Geochem 27:195-212

Hawkins AJS, Bayne B (1992) Physiological interrelations, and the regulation of production. In: Gosling E (ed) The mussel mytilus: ecology, physiology, genetics and culture (developments in aquaculture and. Fisheries science 25). Elsevier, Amsterdam, pp 171-222

Heral M (1993) Why carrying capacity models are useful tools for management of bivalve molluscs culture. In: Dame RF (ed) Bivalve filter feeders in estuarine and coastal ecosystem processes. Springer, Berlin, pp 455-477

Hily C, Grall J, Chavaud L, Lejart M, Clavier J (2013) $\mathrm{CO}_{2}$ generation by calcified invertebrates along rocky shores of Brittany, France. Mar Freshw Res 64:91-101

Howarth RW, Marino R (2006) Nitrogen as the limiting nutrient for eutrophication in coastal marine ecosystems: evolving views over three decades. Limnol Oceanogr 51:364-376

Huang CH, Lin HJ, Huang TC, Su HM, Hung JJ (2008) Responses of phytoplankton and periphyton to system-scale removal of oyster-culture racks from a eutrophic tropical lagoon. Mar Ecol Prog Ser 358:1-12

Jacobs P, Riegman R, van der Meer J (2015) Impact of the blue mussel Mytilus edulis on the microbial food web in the western Wadden Sea. Mar Ecol Prog Ser 527:119-131

Jansen HM (2012) Bivalve nutrient cycling. Wageningen University. PhD dissertation

Jansen HM, Strand Ø, Verdegem M, Smaal A (2012) Accumulation, release and turnover of nutrients (C-N-P-Si) by the blue mussel Mytilus edulis under oligotrophic conditions. J Exp Mar Biol Ecol 416:185-195

Jiang ZJ, Fang JG, Han TT, Mao YZ, Li JQ, Du MR (2014) The role of Gracilaria lemaneiformis in eliminating the dissolved inorganic carbon released from calcification and respiration process of Chlamys farreri. J Appl Phycol 26:545-550

Jones CG, Lawton JH, Shachak M (1994) Organisms as ecosystem engineers. Oikos 69:373-386

Kluger L, Filgueira R, Wolff M (2017) Integrating the concept of resilience into the ecosystembased approach for bivalve aquaculture management. Ecosystems 20:1364-1382

Kusuki Y (1981) Fundamental studies on the deterioration of oyster growing grounds. Bull Hiroshima Fish Exp Stn 11:1-93

Laruelle GG, Dürr HH, Slomp CP, Borges AV (2010) Evaluation of sinks and sources of $\mathrm{CO}_{2}$ in the global coastal ocean using a spatially-explicit typology of estuaries and continental shelves. Geophys Res Lett 37:L15607 
Lejart M, Clavier J, Chauvaud L, Hily C (2012) Respiration and calcification of Crassostrea gigas: contribution of an intertidal invasive species to coastal ecosystem $\mathrm{CO}_{2}$ fluxes. Estuar Coasts 35:622-632

Lerman A, Mackenzie FT (2005) $\mathrm{CO}_{2}$ air-sea exchange due to calcium carbonate and organic matter storage, and its implications for the global carbon cycle. Aquat Geochem 11:345-390

Lowen JB, Innes DJ, Thomson RJ (2013) Predator-induced defenses differ between sympatric Mytilus edulis and M. trossulus. Mar Ecol Prog Ser 475:135-143

Maar M, Nielsen TG, Bolding K, Burchard H, Visser AW (2007) Grazing effects of blue mussel Mytilus edulis on the pelagic food web under different turbulence conditions. Mar Ecol Prog Ser 339:199-213

Maar M, Nielsen TG, Petersen JK (2008) Depletion of plankton in a raft culture of Mytilus galloprovincialis in Ría de Vigo, NW Spain. II. Zooplankton. Aquat Biol 4:127-141

Maar M, Timmermann K, Petersen JK, Gustafsson KE, Storm LM (2010) A model study of the regulation of the blue mussels by nutrient loadings and water column stability in a shallow estuary, the Limfjorden. J Sea Res 64:322-333

Macdonald BA, Thompson RJ (1985) Influence of temperature and food availability on the ecological energetics of the giant scallop Placopecten magellanicus. 1. Growth-rates of shell and somatic tissue. Mar Ecol Prog Ser 25:279-294

Mackenzie FT, Andersson AJ (2013) The marine carbon system and ocean acidification during Phanerozoic time. Geochem Perspect 2:1-22

Mann R, Powell EN (2007) Why oyster restoration goals in the Chesapeake Bay are not and probably cannot be achieved. J Shellfish Res 26:905-917

Millero FJ (1995) Thermodynamics of the carbon dioxide system in the oceans. Geochim Cosmochim Acta 59:661-677

Mistri M, Munari C (2012) Clam farming generates $\mathrm{CO}_{2}$ : a study case in the Marinetta lagoon (Italy). Mar Pollut Bull 64:2261-2264

Mistri M, Munari C (2013) The invasive bag mussel Arcuatula senhousia is a $\mathrm{CO}_{2}$ generator in near-shore ecosystems. J Exp Mar Biol Ecol 440:164-168

Mitchell IM (2006) In situ biodeposition rates of Pacific oysters (Crassostrea gigas) on a marine farm in southern Tasmania (Australia). Aquaculture 257:194-203

Munari C, Rossetti E, Mistri M (2013) Shell formation in cultivated bivalves cannot be part of carbon trading systems: a study case with Mytilus galloprovincialis. Mar Environ Res 92:264-267

Newell RIE (2004) Ecosystem influences of natural and cultivated populations of suspensionfeeding bivalve molluscs: a review. J Shellfish Res 23:51-61

Newell CR, Hidu H (1982) The effects of sediment type on growth-rate and shell allometry in the soft shelled clam Mya arenaria L. J Exp Mar Biol Ecol 65:285-295

Oviatt C, Keller A, Reed L (2002) Annual primary production in Narragansett Bay with no baywide winter-spring phytoplankton bloom. Estuar Coast Shelf Sci 54:1013-1026

Pearson TH, Black KD (2001) The environmental impact of marine fish cage culture. In: Black KD (ed) Environmental impacts of aquaculture. Academic, Sheffield, pp 1-31

Penney RW, Hart MJ, Templeman ND (2008) Genotype-dependent variability in somatic tissue and shell weights and its effect on meat yield in mixed species Mytilus edulis L., M. trossulus (Gould), and their hybrids cultured mussel populations. J Shellfish Res 27:827-834

Petersen JK, Nielsen TG, van Duren L, Maar M (2008) Depletion of plankton in a raft culture of Mytilus galloprovincialis in Ría de Vigo, NW Spain. I. Phytoplankton. Aquat Biol 4:113-125

Pietros JM, Rice MA (2003) The impacts of aquacultured oysters, Crassostrea virginica (Gmelin, 1791) on water column nitrogen and sedimentation: results of as mesocosm study. Aquaculture 220:407-422

Prins TC, Escaravage V, Smaal AC, Peters JCH (1995) Nutrient cycling and phytoplankton dynamics in relation to mussel grazing in a mesocosm experiment. Ophelia 41:289-315 
Prins TC, Smaal AC, Dame RF (1998) A review of the feedbacks between bivalve grazing and ecosystem processes. Aquat Ecol 31:349-359

Rodhouse PG, Roden CM, Hensey MP, Ryan TH (1984) Resource allocation in Mytilus edulis on the shore and in suspended culture. Mar Biol 84:27-34

Rodríguez Álvaro R, Seara Paz G, Pérez Ordóñez JL (2014) Morteros para revestimiento con árido procedente de concha de mejillón. Escola Universitaria de Arquitectura Técnica de A Coruña. Universadide de A Coruña

Rosland R, Strand Ø, Alunno-Bruscia M, Bacher C, Strohmeier T (2009) Applying Dynamic Energy Budget (DEB) theory to simulate growth and bio-energetics of blue mussels under low seston conditions. J Sea Res 62:49-61

Sara G (2007) A meta-analysis on the ecological effects of aquaculture on the water column: dissolved nutrients. Mar Environ Res 63:390-408

Schröder T, Stank J, Schernewski G, Krost P (2014) The impact of a mussel farm on water transparency in the Kiel Fjord. Ocean Coast Manag 101:42-52

Schwinghamer P, Hargrave B, Peer D, Hawkins CM (1986) Partitioning of production and respiration among size groups of organisms in an intertidal benthic community. Mar Ecol Prog Ser 31:131-142

Sepúlveda J, Pantoja S, Hughen K, Lange C, Gonzalez F, Muñoz P, Rebolledo L, Castro R, Contreras S, Ávila A, Rossel P, Lorca G, Salamanca M, Silva N (2005) Fluctuations in export productivity over the last century from sediments of a southern Chilean fjord $\left(44^{\circ} \mathrm{S}\right)$. Estuar Coast Shelf Sci 65:587-600

Smaal AC (1991) The ecology and cultivation of mussels: new advances. Aquaculture 94:245-261

Smaal AC, Prins TC (1993) The uptake of organic matter and the release of inorganic nutrients by bivalve suspension feeder beds. In: Dame RF (ed) Bivalve filter feeders in estuarine and coastal ecosystem processes. Springer, Berlin, pp 271-298

Smaal AC, Vonck A, Bakker M (1997) Seasonal variation in physiological energetics of Mytilus edulis and Cerastoderma edule of different size classes. J Mar Biol Assoc UK 77:817-838

Smaal AC, Schellekens T, van Stralen MR, Kromkamp JC (2013) Decrease of the carrying capacity of the Oosterschelde estuary (SW Delta, NL) for bivalve filter feeders due to overgrazing? Aquaculture 404-405:28-34

Smayda TJ (2008) Complexity in the eutrophicatio-harmful algal bloom relationship, with comment on the importance of grazing. Harmful Algae 8:140-151

Smith RW, Bianchi RS, Allison M, Savage C, Galy V (2015) High rates of organic carbon burial in fjord sediments globally. Nat Geosci 8:450-453

Sonier R, Filgueira R, Guyondet T, Tremblay R, Olivier F, Meziane T, Starr M, Leblanc AR, Comeau LA (2016) Picoplankton contribution to Mytilus edulis growth in an intensive culture environment. Mar Biol 163:72

Souchu P, Vaquer A, Collos Y, Landrein S, Deslous-Paoli JM, Bibent B (2001) Influence of shellfish farming activities on the biogeochemical composition of the water column in Thau Lagoon. Mar Ecol Prog Ser 218:141-152

Stanley SM (1970) Relation of shell form to life habits of the Bivalvia (Mollusca). The Geological Society of America, Inc. Memoir 125

Steffani CN, Branch GM (2003) Growth rate, condition, and shell shape of Mytilus galloprovincialis: responses to wave exposure. Mar Ecol Prog Ser 246:197-209

Strohmeier T (2009) Feeding behavior and bioenergetic balance of the great scallop (Pecten maximus) and the blue mussel (Mytilus edulis) in a low seston environment and relevance to suspended shellfish aquaculture. The University of Bergen. PhD dissertation

Strohmeier T, Duinker A, Strand Ø, Aure J (2008) Temporal and spatial variation in food availability and meat ratio in a longline mussel farm (Mytilus edulis). Aquaculture 276:83-90

Strohmeier T, Strand Ø, Alunno-Bruscia M, Duinker A, Rosland R, Aure J, Erga SR, Naustvoll LJ, Jansen HM, Cranford PJ (2015) Response of Mytilus edulis to enhanced phytoplankton availability by controlled upwelling in an oligotrophic fjord. Mar Ecol Prog Ser 518:139-152 
Suykens K, Schmidt S, Delille B, Harlay J, Chou L, De Bodt C, Fagel N, Borges AV (2011) Benthic remineralization in the northwest European continental margin (northern Bay of Biscay). Cont Shelf Res 31:644-658

Tang Q, Zhang J, Fang J (2011) Shellfish and seaweed mariculture increase atmospheric $\mathrm{CO}_{2}$ absorption by coastal ecosystems. Mar Ecol Prog Ser 424:97-104

Thompson RJ (1984) The reproductive cycle and physiological ecology of the mussel Mytilus edulis in a subarctic, non-estuarine environment. Mar Biol 79:277-288

Trottet A, Roy S, Tamigneaux E, Lovejoy C, Tremblay R (2008) Influence of suspended mussel farming on planktonic communities in Grande-Entrée Lagoon, Magdalen Islands (Québec, Canada). Aquaculture 276:91-102

Vaquer A, Troussellier M, Courties C, Bibent B (1996) Standing stock and dynamics of picophytoplankton in the Thau Lagoon (Northwest Mediterranean coast). Limnol Oceanogr 41:1821-1828

Varhen C, Carrillo S, Ruiz G (2017) Experimental investigation of Peruvian scallop used as fine aggregate in concrete. Constr Build Mater 136:533-540

Waldbusser GG, Powell EN, Mann R (2013) Ecosystem effects of shell aggregations and cycling in coastal waters: an example of Chesapeake Bay oyster reefs. Ecology 94:895-903

Ware JR, Smith SV, Reaka-Kudla MK (1992) Coral reefs: sources or sinks of atmospheric $\mathrm{CO}_{2}$ ? Coral Reefs 11:127-130

Winberg GG (1960) Rate of metabolism and food requirements of fishes. Transl Ser Fish Res Board Can 194:1-202

World Bank, Ecofys and Vivid Economics (2016) State and trends of carbon pricing 2016 (October). World Bank, Washington, DC

Open Access This chapter is licensed under the terms of the Creative Commons Attribution 4.0 International License (http://creativecommons.org/licenses/by/4.0/), which permits use, sharing, adaptation, distribution and reproduction in any medium or format, as long as you give appropriate credit to the original author(s) and the source, provide a link to the Creative Commons license and indicate if changes were made.

The images or other third party material in this chapter are included in the chapter's Creative Commons license, unless indicated otherwise in a credit line to the material. If material is not included in the chapter's Creative Commons license and your intended use is not permitted by statutory regulation or exceeds the permitted use, you will need to obtain permission directly from the copyright holder. 